\section{Weeks (24 Wochen)}

Director: Anne Zohra Berrached. Authors (screenplay): Carl Gerber, Anne Zohra Berrached. Germany, 2016. 103 minutes. UK film release: January 2017. UK DVD release: March 2017

"Women's rights are human rights, and human rights are women's rights", Hillary Clinton told the United Nations Fourth World Conference on Women (Beijing, September 1995). Yet 20 years later she was accused of being a murderer for speaking in favour of legal late-term abortion in her presidential campaign. Her response was nuanced and expressed compassion for women facing the medical realities that drive a late-term abortion. It is a decision that is all too often glossed over or portrayed with tired stereotypes in modern media.

The German film, 24 Weeks, innovatively and convincingly shows the difficulties of such a decision: bombardment with advice, data, and opinions from all directions, the rollercoaster of emotions, and the unforeseeable impact on even the happiest couple and family. It avoids simplistic moralism and focuses on the decision at hand. 24 Weeks premiered at the 2016 Berlinale film festival to much critical acclaim and has since won several awards.

One of the film's strengths is the exquisite performances. Astrid (Julia Jentsch) and Markus (Bjarne Mädel) are a well-off, happy and loving couple and parents of a nice daughter. Astrid enjoys her success as a comedian, an unusual role for Jentsch whom moviegoers have appreciated for her portrayal of women in difficult situations, ranging from Sophie Scholl, who was executed for her resistance to the Nazis, to Effi Briest, the heroine of a late-19th century novel. Astrid's husband and manager Markus loves and supports her in everything. They want a second child but after a routine early pregnancy examination, they learn that the baby will have Down syndrome. The diagnosis hits them hard, but together they learn to deal with the challenge. Their determination gets challenged when additionally, at 6 months into the pregnancy, the fetus is diagnosed with a serious heart defect, which would require major surgery after birth and the child would still have a short life expectancy.

The term ' 24 weeks', which gave the film its title, is the gestational age at which a fetus can survive without the mother. It defines late-term abortion. German law ${ }^{1}$ allows late-term abortion only for a medical indication; that is, when the life or physical or mental health of the pregnant woman is gravely at risk. However, a clinician's medical opinion testifying that the woman would suffer heavily from giving birth to a severely disabled or gravely abnormal child and raising it, and therefore recommending the procedure, suffices to make it legal. Having received all information and the doctor's approval, the decision is solely with the pregnant woman. Since 1995 , late-term abortion only because of a diagnosed disability has no longer been legal. Since 2010, doctors have had an obligation to inform a woman more than 12 weeks' pregnant about all options including abortion, and there is a 3-day waiting period between diagnosis and the procedure (unless there is an acute danger to the woman's life). In addition, a late-term abortion has to be performed by a specialist different from the diagnosing doctor. According to statistics (Die Zeit, 7 July 2016), 90\% of pregnant women (in Germany) informed about a grave disability or defect decide in favour of abortion.

All of the aforementioned details are mentioned in the film. Everywhere around them, Astrid and Markus meet with treatment plans, forecasts, statistics, and all manner of advice. Nothing makes the decision easier, removes doubts or uncertainties. The film is challenging in its depiction of the feelings that the couple go through. They question everything, their relationship, the wish for another child, their plans for the future.

In interviews (e.g. in Cineuropa, 19 February 2016; Die Zeit, 20 September $2016^{2}$ ), director Anne Zohra Berrached spoke about the taboo of late-term abortion and her difficulties in finding women who would share their experiences. She insisted on filming with medical experts (Professor Martin Kostelka, Senior Consultant in Pediatric Surgery, Leipzig Cardiac Centre University Hospital, Leipzig; Professor Holger Stepan, Director of Obstetrics, University of Leipzig, Leipzig, Germany), nurses and a midwife. In her "a nonrefabricated approach", the specialists would say and do as they did in such situations and let the actors act spontaneously. The effect is a story that feels real and powerful.

This abortion film goes beyond the question of a woman's right to choose and the often one-sided movie representation of pregnant teenagers not ready for parenthood. Do the opportunities of prenatal diagnosis drive a perceived obligation to spare a painfilled life? Is there a right to have a healthy child? How do women and couples deal with the pressure to have a healthy child? How can one decide whether a life is worth living or avoidable suffering? Given the diagnostic possibilities, is there an obligation to spare society the costs of a child that will not live long and will need extensive special care? The film does not try to answer such questions, but instead focuses on the emotional side and the difficulty, loneliness, and often shame of the decision. "Nobody can make this decision who does not have to make it", says the midwife to Astrid in her despair. "Nobody can make it for you. Nobody has a right to judge it." The film also does not shy away from depicting late-term abortion in real terms. It provides accurate information about a process shrouded in myths and misinformation.

24 Weeks is bound to draw a very different reaction in the USA or in Ireland, Poland, and other countries where abortion is a more polarising topic, than in Germany, which has a liberal abortion law but also a low abortion rate.

In his campaign for the US presidency, Donald Trump declared, inaccurately, that a late-term abortion "means that a woman can decide to have an abortion for any reason right up to the day before she is to deliver". It is ironic that this fictional film is more accurate about abortion decisions and facts than is seen in government policy debates.

\section{Reviewed by Waltraud Maierhofer}

Professor of German, International Programs, Department of German, College of Liberal Arts \& Sciences, University of lowa, lowa City, IA, USA; waltraud-maierhofer@uiowa.edu

Competing interests None declared.

Provenance and peer review Not commissioned; internally peer reviewed.

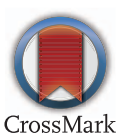




\section{REFERENCES}

1 German Law Archive. Criminal Code (Strafgesetzbuch, StGB). Section 218a: Exemption from Punishment for Termination of Pregnancy. http://germanlawarchive. iuscomp.org/? $\mathrm{p}=752 \# 218 \mathrm{a}$ [accessed 28 November 2016].

2 Schwickert M. "24 Wochen”: Die Frau muss hier über das Leben ihres Kindes entscheiden”. Interview with Anne Zohra Berrached [in
German]. Zeit Online, 20 September 2016. http://www.zeit.de/kultur/film/2016-09/24wochen-film-anne-zohra-berrachedschwangerschaftsspaetabbruch [accessed 28 November 2016]. 